\title{
PROSES PENDALAMAN INFORMASI BERBASIS INFORMASI AWAL LINE@ BEM FIKOM UNPAD \\ (Studi Fenomenologi Proses Pendalaman Informasi Akademik dan Non Akademik Berbasis Informasi Awal LINE@ BEM Fikom Unpad Oleh Mahasiswa Fikom Unpad)
}

Ashri Nooraida Permana ${ }^{1}$, Pawit M. Yusup ${ }^{2}$, Nuning Kurniasih ${ }^{3}$

${ }^{1}$ IEC Jatinangor, ${ }^{2,3}$ Program Studi Ilmu Perpustakaan Universitas Padjadjaran

1ashrinooraida@gmail.com, ${ }^{2}$ pawit.m.yusup@unpad.ac.id

3nuning.kurniasih@unpad.ac.id

ABSTRACT - The purpose of this study is to disscussed about how students in Fakultas Ilmu Komunikasi Universitas Padjadjaran (FIKOM UNPAD) doing the process of deepening on information in academic and non academic fields based on the first information source, which is LINE@BEM Fikom Unpad. This research used a qualitative method with phenomenological tradition. The data accumulation was done by indepth interview, observation, and by literature study. The informants are nine students from various departments in FIKOM UNPAD, who have been accessing LINE@BEM Fikom Unpad for obtained infor information. The results of this study indicate that all informants doing deepening on the information that received from LINE@BEM Fikom Unpad to various sources of information, whether it is using technology based communication and information media or discussion with their colleagues.

Keywords: The process of deepening information, LINE, students of Fikom Unpad

ABSTRAK - Penelitian ini bertujuan untuk mengidentifikasi bagaimana mahasiswa Fakultas Ilmu Komunikasi Universitas Padjadjaran (FIKOM UNPAD) dalam melakukan proses pendalaman terhadap informasi yang telah mereka peroleh dari sumber informasi awal, yaitu LINE@ BEM Fikom Unpad. Metodologi penelitian yang digunakan dalam penelitian ini adalah metode kualitatif dengan tradisi fenomenologi. Pengumpulan data dilakukan dengan cara wawancara mendalam, observasi, dan studi pustaka. Informan merupakan sembilan orang mahasiswa dari berbagai jurusan yang ada di Fikom Unpad, yang aktif dalam mengakses LINE@ BEM Fikom Unpad untuk mendapatkan informasi. Hasil penelitian ini menunjukkan bahwa semua informan melakukan pendalaman atas informasi yang mereka peroleh dari LINE@
BEM Fikom Unpad kepada berbagai sumber informasi lainnya, baik itu dengan menggunakan media berbasis teknologi komunikasi dan informasi maupun dengan melakukan forum diskusi bersama rekan sejawat dikampusnya.

Kata kunci: Proses pendalaman infromasi, LINE, Mahasiswa Fikom Unpad

\section{PENDAHULUAN}

Penggunaan aplikasi instant messaging saat ini telah menjadi suatu fenomena baru yang terjadi di kalangan mahasiswa Fikom Unpad. Berdasarkan hasil pengamatan peneliti di lapangan, hal tersebut terjadi karena dalam lingkungan sosialnya, yaitu kehidupan di kampus Fikom Unpad, mayoritas mahasiswanya menggunakan aplikasi LINE. Keberadaan LINE seakan telah menjadi suatu kebutuhan utama dalam kehidupannya, sampai telah menjadi lifestyle baik dalam hal berkomunikasi dengan sesama sampai untuk mendapatkan informasi dalam kehidupan sehari-hari.

Berdasarkan hasil pengamatan pada 5 April 2016, LINE@ BEM Fikom Unpad telah memposting sebanyak 640 informasi dan memiliki 3.574 friends yang terdiri dari mahasiswa berbagai jurusan di Fikom Unpad. Konten informasi yang terdapat pada LINE@ 
BEM Fikom Unpad mencakup berita mengenai isu-isu terbaru di bidang akademik dan non akademik seperti info beasiswa, kalender akademik, acara seminar, program kerja BEM Fikom seperti Fikompetition, Fikom Languange; event Fikom seperti Pameran; lowongan magang atau kerja; apresiasi prestasi anak Fikom; informasi kegiatan Himpunan dan Unit Kegiatan Mahasiswa Fikom; serta informasi yang khususnya dalam lingkup fakultas, umumnya dalam lingkup kampus Universitas Padjadjaran, yang harus diketahui oleh Mahasiswa Fikom Unpad.

Media LINE memang tidak seperti search engine yang menyediakan fasilitas kolom carian secara khusus. Sebagai aplikasi instant messaging dan media penyedia informasi, LINE@BEM Fikom Unpad berperan sebagai pintu awal bagi mahasiswa Fikom Unpad untuk mendapatkan informasi terbaru dalam bidang akademik dan non-akademik di Fikom Unpad. Setelah memperoleh informasi dari LINE@ BEM Fikom, mahasiswa akan melakukan pendalaman atas nilai dan makna dari informasi yang telah diperolehnya kepada media atau sumber informasi lain dengan tujuan mendapatkan informasi yang lebih lengkap dan jelas untuk meningkatkan pemahaman akan informasi yang telah diperolehnya.

Pendalaman memiliki arti sebuah proses, cara, perbuatan mendalami. Maksud dari mendalami adalah perbuatan yang menciptakan suatu paham yang benar-benar, mencari makna yang betul-betul terasa pada dirinya sehingga menambah penguasaan dan kemampuan terhadap sesuatu hal. Dalam konteks penelitian ini, mahasiswa Fikom Unpad berinteraksi dengan media informasi yang dipilihnya untuk mendapatkan informasi akademik dan nonakademik yang ada di kampus Fikom Unpad. Setelah mendapatkan informasi dari media awal tersebut, maka mereka akan secara aktif untuk mencari informasi-informasi baru yang relevan dengan topik informasi yang telah diperolehnya, dengan melakukan pencarian lanjutan kepada berbagai media informasi lain. Seluruh kegiatan ini selanjutnya disebut dengan proses pendalaman informasi.

Proses pendalaman informasi dimulai dengan adanya keinginan rasa ingin tahu yang lebih dari dalam diri mahasiswa Fikom Unpad untuk lebih memahami isu-isu terbaru apa saja yang sedang terjadi dikampusnya. Mereka menyebut kondisi tersebut dengan istilah "kepo". Untuk mengatasi rasa kepo tersebut, mereka akan melanjutkan pencariannya dengan mengakses berbagai sumber informasi lain untuk mendapatkan informasi-informasi baru yang relevan dengan topik berita yang telah diperoleh sebelumnya. Sumber informasi lain tersebut berupa media yang berbasis teknologi informasi dan komunikasi, sampai dengan melakukan forum diskusi bersama rekan sejawat di kampusnya. Hal tersebut bertujuan untuk mempertajam dan memperdalam nilai dan makna dari informasi yang awalnya telah mereka peroleh dari LINE@ BEM Fikom Unpad.

Penelitian ini akan memfokuskan pada bagaimana cara, proses, dan pengalaman yang dimiliki oleh mahasiswa Fikom Unpad sebagai 
pencari informasi dalam melakukan pendalaman informasi yang telah diperolehnya. Pencarian informasi merupakan bagian dari proses pendalaman informasi. Hal tersebut dikarenakan disaat melakukan pendalaman informasi, secara tidak langsung mereka juga melakukan pencarian informasi kepada berbagai sumber, dengan memiliki suatu fokus tujuan informasi yang ingin dicapai.

Penelitian ini bertujuan untuk mendeskripsikan bagaimana pengalaman mahasiswa Fikom Unpad dalam melakukan proses pendalaman informasi yang diperoleh dari LINE@BEM Fikom Unpad. Konten dari informasi tersebut mencakup isu-isu terbaru di bidang akademik dan non- akademik yang ada di lingkungan kampus Fikom Unpad. Disamping itu penelitian ini bertujuan untuk mengembangkan pengetahuan di bidang Ilmu Informasi dan Perpustakaan, khususnya dalam bidang perilaku informasi berbasis media teknologi informasi dan komunikasi.

\section{TINJAUAN PUSTAKA}

Mahasiswa sebagai kaum terpelajar tentunya memiliki kebutuhan yang tinggi terhadap informasi, terutama informasi yang dapat menunjang kegiatan perkuliahannya. Seperti yang dikemukakan oleh Katz, Gurivech, dan Haas dalam Tan, bahwa "people with higher levels of education reported more needs to be important than prople with less education" (Tan, Mass Communication Theories and Research). Yang berarti seseorang dengan tingkat pendidikan yang tinggi memiliki kebutuhan yang lebih tinggi, lebih banyak, dibandingkan dengan orang-orang yang kurang berpendidkan.

Pengguna informasi seperti mahasiswa, dapat menggunakan media komunikasi yang bermacam-macam bentuknya dengan tujuan mencari dan menemukan informasi yang diinginkannya. Dalam pencarian informasinya individu akan berinteraksi atau menggunakan sistem pencarian manual melalui media tekstual, atau juga dapat menggunakan media yang berbasis komputer seperti internet. Dengan kata lain, perilaku pencarian informasi adalah suatu kegiatan atau aktivitas dari individu dalam mencari informasi yang dibutuhkan atau diinginkan dengan suatu tujuan tertentu (Yusup \& Subekti, 2010).

T.D Wilson dalam jurnalnya yang berjudul On user studies and information needs (2006), mendeskripsikan sebuah model perilaku informasi. Dalam model ini, dinyatakan bahwa perilaku pencarian informasi merupakan hasil dari adanya kesadaran atas beberapa kebutuhan yang dirasakan oleh pengguna (Wilson, 2006). Perilaku tersebut memungkinkan pengguna untuk mengakses kepada sistem formal yang dapat didefinisikan sebagai sistem informasi (seperti perpustakaan, on-line services, pusat informasi).

Terdapat pendekatan pencarian informasi berdasarkan aspek perasaan (afektif), pemikiran (kognitif) dan tindakan (fisik) yang dilihat dari perspektif seseorang dalam melakukan pencarian informasi. Pendekatan tersebut diungkapkan oleh Carol C. Kuhlthau dalam jurnalnya yang berjudul "Inside the Search Process: Information Seeking from the User's 
Perspective” sebagai Information Search Process (ISP). Dalam modelnya, Kuhlthau menggambarkan kegiatan pencarian informasi sebagai sebuah proses konstruksi yang dilalui oleh seseorang dari tahap ketidakpastian (uncertainty) menuju pada tahap pemahaman (understanding). Berdasarkan pendekatan tersebut Kuhlthau membagi pada 6 tahapan dalam pencarian informasi, yaitu dari awalan (initiation), pemilihan (selection), penjelajahan (exploration), penyusunan (formulation), pengumpulan (collection), dan penyajian (presentation) (Kuhlthau, Inside the Search Process: Information Seeking from the User's Perspective, 1991).

Reijo Savolainen dalam jurnalnya yang berjudul "Network competence and information seeking on the internet" mengusulkan sebuah model yang bernama Social Cognitive Model of Network Competence. Model tersebut menjelaskan tentang kemampuan atau ketidakmampuan seseorang dalam menemukan informasi di sebuah jaringan komputer. Pada saat ini, kompetensi seseorang dalam memanfaatkan jaringan komputer ketika sedang membutuhkan informasi menjadi salah satu faktor yang penting. Seseorang tidak hanya harus 'melek informasi' (information literate), namun juga harus 'melek jaringan' (network literate) (Savolainen, 2002).

\section{METODE PENELITIAN}

Penelitian ini dilakukan dengan menggunakan metode kualitatif dengan tradisi fenomenologi, karena yang diteliti adalah pandangan dan pengalaman dari masing-masing individu dalam melakukan pendalaman informasi dari media LINE. Dalam pandangan fenomenologi, peneliti berusaha memahami arti dari peristiwa dan pengalaman dari sudut pandang orang yang mengalaminya secara langsung, yang dialami informan mengenai bagaimana pengalaman mereka dalam mereka mengakses berbagai media untuk memperdalam informasi yang telah diperolehnya.

Adapun yang menjadi subjek dalam penelitian ini adalah Mahasiswa Fakultas Ilmu Komunikasi (S1) Universitas Padjadjaran. Peneliti menggunakan teknik sampling untuk menentukan informan yang diwawancarai secara purposive sampling, yang merupakan teknik pengambilan sampel sumber data dengan pertimbangan tertentu. Pertimbangan tertentu yang dimaksud dalam penelitian ini yaitu mahasiswa Fikom Unpad yang menjadi friend aktif minimal selama 5 bulan dalam mengakses LINE@BEM Fikom Unpad untuk mendapatkan informasi.

\section{HASIL DAN PEMBAHASAN}

LINE merupakan aplikasi instant messaging yang dapat menjadi media informasi dengan adanya fitur terbaru LINE@ (LINE Official Account) yang dapat digunakan untuk menghimpun dan mendiseminasikan informasi kepada pengguna LINE yang telah menjadi friend dari akun tersebut. Sebagai media informasi, LINE@ tidak seperti search engine yang memungkinkan penggunanya untuk memasukkan query pencarian. Keberadaan 
LINE@ BEM Fikom Unpad disini bukan sebagai media telusur, akan tetapi sebagai media penyedia informasi yang menjadi sumber awal bagi mahasiswa Fikom Unpad untuk mendapatkan informasi-informasi terbaru mengenai isu- isu terbaru terkait akademik dan non-akademik yang ada di lingkungan kampusnya.

Dari hasil penelitian ditemukan bahwa seluruh informan yang diwawancarai melakukan pendalaman atas informasi yang menurutnya menarik serta sesuai dengan kebutuhannya, yang diperoleh dari LINE@ BEM Fikom Unpad. Mereka menyatakan bahwa meskipun LINE@ BEM Fikom Unpad selalu memberikan informasi yang up to date terhadap isu-isu akademik dan non-akademik di Fikom Unpad, namun terkadang konten informasinya tidak terlalu mendetail. Hal tersebut mengharuskan mereka untuk mengakses lagi kepada berbagai sumber informasi lain untuk mendapatkan keterangan-keterangan pelengkap yang terkait dengan topik informasi yang ingin lebih dipahaminya.

Setelah mendapatkan informasi dari sumber awal, yaitu LINE@ BEM Fikom Unpad, mereka masih merasakan adanya kekurangan dan keinginan untuk mendapatkan informasi-informasi pelengkap lainnya yang dapat menambah nilai dan makna dari informasi yang telah diperoleh sebelumnya. Mereka menyebut kondisi ini dengan istilah kepo, yang mendefinisikan suatu keadaan dimana timbul keinginan dari dalam dirinya untuk mendapatkan informasi selengkap- lengkapnya mengenai topik dari berita yang ingin sekali dipahaminya dengan melakukan berbagai cara, yaitu mengakses kepada berbagai macam sumber informasi yang memiliki konten informasi terkait. Hal tersebut bertujuan untuk memperdalam dan memperkaya pemahaman akan informasi yang telah diperolehnya, untuk menggali informasi-informasi pendukung yang bisa memberikan keterangan tambahan, dan untuk melengkapi kejelasan informasi yang awalnya telah diperoleh dari LINE@ BEM Fikom Unpad.

Setelah mendapatkan informasi dari LINE@ BEM Fikom Unpad baik itu dari pesan broadcast ataupun timeline, mahasiswa Fikom Unpad akan mulai memperdalam makna dan nilai dari informasi yang telah diperolehnya tersebut dengan cara melanjutkan proses pencarian pada berbagai media dan sumber informasi lainnya. Proses pendalaman kepada berbagai sumber informasi dengan memiliki suatu fokus yaitu topik dari berita yang ingin dipahami sedalam-dalamnya. Terdapat berbagai cara yang dilakukan oleh mahasiswa Fikom Unpad dalam melakukan pendalaman informasi yang diperolehnya dari LINE@ BEM Fikom Unpad. Cara-cara tersebut yakni: (1) Melakukan forum diskusi (brainstorming); (2) Mengakses media informasi lain; dan (3) Mengklarifikasi informasi.

Mahasiswa Fikom Unpad memperdalam hasil informasi yang telah diperolehnya dari LINE@ BEM Fikom Unpad, dengan melakukan forum diskusi. Kegiatan forum diskusi biasanya dilakukan bersama teman- 
teman, senior, forum himpunan mahasiswa, dan orang yang dianggap lebih mengerti akan isu yang sedang menjadi pembahasan. Hal tersebut dilakukan oleh mahasiswa Fikom Unpad karena dengan melakukan brainstorming, mereka akan saling bertukar pikiran dan pendapat mengenai suatu topik sehingga dapat memperoleh informasi tambahan atau keterangan lebih lanjut dari pihak-pihak yang lebih mengetahui tentang isu-isu yang sedang mereka ingin ketahui.

Pendalaman atas informasi yang telah diperoleh dari LINE@ BEM Fikom Unpad juga dapat dilakukan dengan melakukan pencarian lanjutan kepada media lain. Dalam penelitian ini, mahasiswa Fikom Unpad tidak hanya menggunakan satu media dalam proses pencarian informasi lanjutan dengan tujuan untuk mendalami informasi yang telah diperolehnya. Dengan keterampilan menggunakan berbagai media teknologi informasi seperti aplikasi instant messaging dan Website, mereka menggunakan keterampilan tersebut untuk melakukan pendalaman informasi. Media berteknologi informasi atau sumber informasi lain yang digunakan oleh mahasiswa Fikom Unpad diantaranya adalah: (1) Website Fikom; (2) Website Unpad; (3) Instagram; (4) Facebook; (5) Twitter; dam (6) Akun LINE lain seperti Fikom HI, Hima Mankom, Hima Humas, Himaka, BKI, Kema Unpad, Unpad Jawara Pimnas, Info Mahasiswa Unpad.

Website Fikom dipilih sebagai media dalam melakukan pendalaman informasi. Hal tersebut dikarenakan mahasiswa Fikom Unpad percaya bahwa data-data yang terdapat pada website tersebut lengkap dan pasti akurat, karena dikelola langsung oleh pihak Humas Fikom Unpad. Website Unpad juga digunakan dalam kegiatan pendalaman informasi oleh mahasiswa Fikom. Pada saat melihat informasi mengenai beasiswa atau exchange student dari LINE@BEM Fikom Unpad, mereka memiliki keinginan untuk mencari lagi keteranganketerangan tambahan yang dapat lebih melengkapi informasi tersebut kepada Website Unpad. Mereka menganggap bahwa website Fikom dan Website Unpad memiliki kontenkonten yang berkaitan dengan informasi yang sedang mereka inginkan untuk diperdalam lagi pemahamannya. Selain itu terdapat fasilitas search atau kolom carian pada masing-masing website. Hal tersebut dapat memudahkan mahasiswa Fikom Unpad untuk memasukan keyword atas topik informasi yang ingin diperolehnya.

Berbagai aplikasi instant messaging dan media social networking juga digunakan oleh mahasiswa Fikom Unpad dalam melakukan pendalaman atas informasi yang diperolehnya dari LINE@ BEM Fikom Unpad. Aplikasi instant messaging dan media social networking tersebut diantaranya adalah Instagram, Facebook, Twiter, dan akun LINE terkait lainnya. Pada saat mereka membaca isu yang sedang ramai diperbincangkan di LINE@ BEM Fikom Unpad, maka muncul sebuah keinginan dari dalam diri mereka untuk mencari tahu lebih dalam lagi tentang 
subjek yang sedang diperbincangkan dalam topik tersebut. Biasanya mereka akan mengakses Instagram, yaitu sebuah media social networking yang memungkinkan penggunanya untuk berbagi foto dan video. Instagram saat ini juga merupakan salah satu media social networking yang populer dikalangan mahasiswa. Biasanya jika ingin mengetahui lebih dalam atas informasi mengenai seseorang, mereka akan langsung mencari akun dari orang yang bersangkutan pada kolom search yang ada di Instagram. Mereka mengakses Instagram dengan tujuan untuk mengatasi rasa penasaran mereka terhadap orang yang sedang menjadi topik pembahasan dengan cara mencari tahu lebih dalam lagi tentang profil dari orang-orang yang sedang menjadi bahan pembicaraan di postingan yang ada di LINE@ BEM Fikom Unpad. Selain Instagram, mahasiswa Fikom juga seringkali membuka Twitter dan Facebook untuk mendapatkan informasi penguat dari topik yang sedang menjadi pembahasan di LINE@ BEM Fikom Unpad. Hal tersebut dikarenakan mereka berteman dengan pengurus BEM di Twitter dan Facebook, sehingga jika ada berita yang diposting oleh pengurus BEM yang menjadi teman mereka dapat membacanya.

Mahasiswa Fikom Unpad juga dapat melakukan pendalaman atas informasi yang telah diperolehnya dari LINE@ BEM Fikom Unpad dengan mengakses akun LINE lain yang terkait dengan topik yang menjadi pembahasan. Akun LINE lain tersebut diantaranya adalah Fikom HI, Hima Mankom, Hima Humas, Himaka, BKI, Kema Unpad, Unpad Jawara
Pimnas, dan Info Mahasiswa Unpad. Fikom HI diakses oleh mahasiswa Fikom untuk mendapatkan informasi tambahan mengenai advokasi dan pelayanan mahasiswa. Mereka menganggap informasi yang ada pada Fikom HI lebih jelas dan detail, karena memang akun tersebut dikhususkan untuk informasi mengenai advokasi dan pelayanan mahasiswa di Fikom Unpad.

Pada saat LINE@ BEM Fikom Unpad memberikan informasi yang topiknya mengenai Unpad secara keseluruhan, mahasiswa Fikom akan mengakses kembali kepada akun LINE lain yang memiliki konten informasi yang lebih luas. Akun LINE tersebut adalah Info Mahasiswa Unpad, Unpad Jawara Pimnas, dan Kema Unpad. Hal tersebut bertujuan agar selain mereka mendapatkan informasi dari media khusus internal Fikom (LINE@ BEM Fikom Unpad), mereka juga mendapatkan informasi tambahan dari media eksternal Fikom yang mencakup Unpad secara keseluruhan (Info Mahasiswa Unpad, Unpad Jawara Pimnas, Kema Unpad). Misalnya pada saat Pemilu Presiden Unpad (Prama). Topik tersebut sempat hangat diperbincangkan di LINE@ BEM Fikom Unpad, karena salah satu calonnya adalah mahasiswa Fikom. Untuk mencari informasiinformasi tambahan mengenai Prama tersebut, maka mereka mengakses kepada akun LINE lain yang mencakup Unpad secara keseluruhan untuk menambah pengetahuan mereka atas topik yang sedang menjadi pembahasan dari media eksternal Fikom. 
Dalam melakukan pendalaman informasi melalui akun LINE lain, mahasiswa Fikom Unpad akan mengakses dari akun yang paling luas sampai ke akun dari bagianbagian BEM Fikom. Akun paling luas tersebut adalah akun LINE yang cakupan informasinya mengenai Unpad keseluruhan, dan akun dari bagian-bagian BEM Fikom seperti dari Himpunan Mahasiswa (Hima) dan Unit Kegiatan Mahasiswa (UKM) yang ada di Fikom Unpad. Hima dan UKM di Fikom masing-masing memiliki akun officialnya tersendiri. Disaat LINE@ BEM Fikom Unpad memposting informasi yang berkaitan dengan Hima dan UKM yang ada di Fikom, mereka akan langsung mengakses akun LINE dari Hima dan UKM yang bersangkutan. Hal tersebut dikarenakan mereka ingin mendapatkan informasi tambahan langsung dari akun LINE yang sedang menjadi topik pembahasan. Misalnya pada saat LINE@ BEM Fikom Unpad memposting berita mengenai Ketua Hima Mankom yang baru, maka mereka akan mengakses LINE dari Hima Mankom agar mendapatkan keterangan-keterangan tambahan langsung dari akun LINE yang bersangkutan.

LINE memang tidak menyediakan fitur search untuk setiap informasi yang ada pada akunnya. Pengguna akan melakukan scrolling, yaitu membaca dari yang paling baru sampai yang terdahulu, untuk membaca informasi yang tersedia pada sebuah akun. Informasi pada LINE berurut dari waktu update terbaru, sampai yang terlama. Berdasarkan hasil pengamatan, biasanya mahasiswa Fikom melakukan pendalaman informasi terhadap informasi terbaru atau suatu isu yang memang sedang happening pada saat itu. Oleh karena itu meskipun tidak tersedia kolom carian pada LINE, mereka tetap dapat mendapatkan informasi yang mereka inginkan karena postingan informasi yang sedang happening pada saat itu pasti berada pada urutan paling atas, meskipun tidak menutup kemungkinan mengharuskan mereka untuk tetap melakukan scrolling pada akun LINE tersebut.

Dalam melakukan proses pendalaman informasi, terdapat suatu aktivitas dimana mahasiswa Fikom Unpad mencari pembenaran atas informasi yang diperolehnya. Seperti yang dinyatakan David Ellis bahwa "verifying is an activities associated with checking the accuracy of information” (Ellis, Cox, \& Hall, 1993). Mereka melakukan pengklarifikasian terhadap informasi yang diperoleh dari LINE@ BEM Fikom Unpad kepada sumber informasi lain. Hal tersebut bertujuan untuk mendapatkan informasi yang memang telah terbukti kebenarannya. Selain untuk mengklarifikasi kebenaran informasi, hal tersebut juga dapat meningkatkan pemahaman mereka terhadap makna dan nilai dari suatu informasi. Cara klarifikasi yang dilakukan diantaranya adalah dengan: (1) Membahasnya kedalam forum diskusi (brainstorming);

Bertanya langsung kepada pihak yang bersangkutan; dan (3) Mengakses kepada sumber informasi lain

Melakukan klarifikasi dengan membahas informasi tersebut kedalam sebuah forum 
diskusi, dilakukan oleh mahasiswa Fikom Unpad untuk mengatasi rasa kebingungan atau keraguan dengan cara bertukar fikiran (brainstorming). Diskusi tersebut bisa dilakukan dengan teman-teman, grup Hima, grup BEM, grup angkatan, dan grup lainnya. Biasanya dalam forum tersebut terdapat seseorang yang lebih memahami terhadap topik yang sedang menjadi pembahasan, sehingga memudahkan mereka untuk mendapatkan pembenaran atas informasi yang awalnya mereka ragukan kebenarannya.

Pengklarifikasian informasi juga dapat dilakukan dengan bertanya langsung kepada pihak terkait yang bersangkutan dengan topik yang sedang menjadi pembahasan. Mereka menganggap jika langsung bertanya pada pihak yang bersangkutan, mereka akan mendapatkan informasi yang benar terpercaya karena berasal langsung dari sumbernya. Adapula yang mengklarifikasi dengan pengurus BEM yang mereka kenali, karena pengurus dari lembaga eksekutif mahasiswa yang ada di Fikom dianggap lebih memahami terhadap isu yang sedang menjadi pembahasan di LINE@ BEM Fikom Unpad. Jika informasi tersebut mengenai akademik, maka mereka akan mencari informasi kepada Sub Bagian Pendidikan (SBA) atau kepada dosen, untuk mendapatkan informasi yang akurat. Penggunaan media lain seperti Web Unpad juga bisa digunakan untuk mengklarifikasi informasi. Hal tersebut dikarenakan informasi yang ada pada Web Unpad memang sudah pasti akurat dan terpercaya kebenarannya.
Namun ada pula yang menganggap bahwa informasi yang disampaikan dari LINE@ BEM Fikom Unpad sudah pasti benar dan dapat dipercaya, sehingga tidak perlu tindakan lanjutan untuk mengklarifikasi kebenarannya. Hal tersebut dikarenakan LINE@ BEM Fikom Unpad merupakan akun resmi yang dikelola oleh BEM Fikom, yang tujuan dibentuknya adalah untuk menjadi sebuah media yang menghimpun dan menyebarkan informasi mengenai Fikom Unpad secara up to date dan terpercaya. Penulis menggambarkan hal ini dalam gambar di bawah ini.

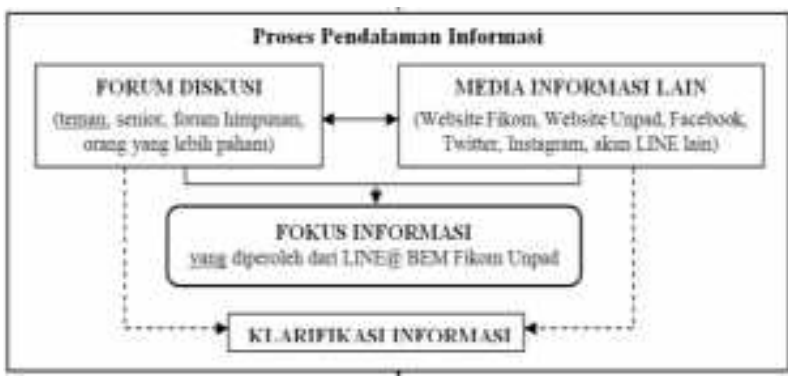

Gambar 1. Model Alur Proses Pendalaman

Informasi yang diperoleh dari LINE@ BEM

Fikom Unpad Oleh Mahasiswa

Sumber: Pengolahan data hasil penelitian

\section{SIMPULAN}

1. Mahasiswa Fikom Unpad memiliki pengalaman dalam memperoleh pencarian informasi melalui LINE@ BEM dalam berbagai cara. Cara tersebut diantanya melakukan forum diskusi (brainstorming) dengan teman, senior, forum himpunan mahasiswa, dan orang yang dianggap lebih memahami topik tersebut; mengakses media informasi lain seperti Website Fikom, Website Unpad, Instagram, Facebook, 
Twitter, dan akun LINE lain yang terkait dengan topik pembahasan

2. Selama melakukan proses pendalaman informasi, secara tidak langsung mereka melakukan klarifikasi informasi untuk mendapatkan informasi yang benar-benar jelas dan terbukti akurat kebenarannya.

\section{DAFTAR PUSTAKA}

Ellis, D., Cox, D., \& Hall, K. (1993, Desember). A Comparison of The Information Seeking Patterns of Researchers in the Physical and Social Science. Retrieved from Journal of Documentation Vo.49 No. 4: 356-369:

http://www.researchgate.net/publicatio n/235802762_A_Comparison_of_the_Inf ormation_Seeking_Patterns_of_Researc hers_in_the_Physical_and_Social_Scienc es?uid=uITD71oOEzzdg6yGP6ssgraQ1h 0YqEtM741m\&cp=re361_x_p2\&ch=reg

Kuhlthau, C. C. (1991, Mei). Inside the Search Process: Information Seeking from the User's Perspective. Retrieved from Journal of The American Society for Information Science: https://comminfo.rutgers.edu/ kuhlthau/d ocs/ELIS\%203E.pdf
Kuhlthau, C. C. (Kuhlthau, C. C. 1991, Mei). Inside the Search Process: Information Seeking from the User's Perspective. Retrieved from Journal of The American Society for Information Science 42: https://comminfo.rutgers.edu/ kuhlthau/d ocs/ELIS\%203E.pdf

Savolainen, R. (2002, September). Network Competence and Information Seeking On The Internet: From Definitions Towards a Social Cognitive Model. Retrieved from Journal of Documentation: http://eresources.perpusnas.go.id:2057/ docview/217957499/EF43698DB5864AF EPQ/11?accountid=25704Savolainen

Tan, A. (1981). Mass Communication Theories and Research. Colombus: Ohio Grid Publishing.

Wilson, T. D. (2006). 60 Years Of The Best In Information Research: On User Studies and Information Needs. Retrieved from Journal of Documentation Vol. 62 No. 6: 658-670:

http://www.asiaa.sinica.edu.tw/ ccchian g/GILIS/LIS/p658-Wilson.pdf

Yusup, P. M., \& Subekti, P. (2010). Teori dan Praktik Penelusuran Informasi (Information Retrieval). Jakarta: Kencana. 